\title{
Case Study Communication of Social Media and Business Startup Infokost.id
}

\author{
Nur Fadhli Fajarr ${ }^{1}$, Henni Gusfa ${ }^{2}$ \\ \{nurfadhlifajar@gmail.com ${ }^{1}$,henni.gusfa@gmail.com² \\ Universitas Mercu Buana, Indonesia ${ }^{1,2}$
}

\begin{abstract}
In the current digital era, many startups are starting to emerge, but from most only a few companies or organizations that develop startups in Indonesia are able to survive and succeed in making a profit. Why can a startup really succeed in building its business while other startups fail and give up? Some reasons for startup failure include, the absence of the right customer, unable to find a suitable business model, high level of competition, large funding requirements, a less solid team, the business idea itself, and also the wrong time, and many others. The purpose of this research is to analyze and find out what factors influence startups that can survive and develop, especially in Indonesia. The research methodology used is a case study with the subject of infokost.id Startup research with a qualitative approach. The results of this study are the determinants of business success to start a business on startup Infokost.id is a good Team, the right time management, as well as adequate ideas and funding. This shows that the quality of good human resources and the right timing greatly influences the success of the business which is still in its initial stages.
\end{abstract}

Keywords: Startup, Business, Business Model, Infokost.id.

\section{Introduction}

Entrepreneurship today is pioneering business or known as the Start up. Startup term in the past two years. This has become the new belle in Indonesia. Just last June, The Ministry of Communication and Information (Kemenkominfo) and Kibar succeeded organizing the National 1,000 Digital Start-up Movement, which activity aims to deliver quality startups that are present as solutions to problems in Indonesia. One indication of stretching is the existence of four digital statuses unicorns in the country, most in Southeast Asia. Which is even in total only has seven unicorns, including four from Indonesia, namely Gojek, Tokopedia, Traveloka and Bukalapak. We Are Social collaborates with Hootsite periodically presents trend data about the internet and social media at the end of January 2019. Summary/data of internet trends and social media in 2019 in Indonesia is the Total Population (total population) of 268.2 million (up 1\% or around 3 million population from 2018). Unique Mobile Users: 355.5 million (down 19\% or around 83 million from 2018). Internet users: 150 million (up 13\% or thereabouts 17 of 2018). Active Social Media Users: 150 million (up 15\% or thereabouts 20 from 2018). Mobile Social Media Users: 130 million (up 8.3\% or around 10 from 2018).

Ooi and Ahmad [1], explained that the emergence of these businesses was carried out individually. The right motivational aspect is very important for business start-ups or prospective entrepreneurs to get into the business. Drucker in Paunescu [2] states "everyone 
who starts a new business is entrepreneurial". A young entrepreneur in particular who moves in the business Start-up has an innovation to produce creative solutions related to the market whose needs have not been met and create new types of value for customers. Start-up phenomena are also supported by an explosion of social media users. This social media platform that prioritizes networking concepts is very helpful for business pioneers to publish their Start-up, in order to attract potential investors. The flow of interaction that occurs in social media is also considered effective for start-ups as a branding tool. Over the years, social media has been widely used as an effective channel for start-ups to reach potential consumers and expand the product/service of a start-up. The important role of social media is inseparable from other marketing tools because they are interrelated with one another. Abdullah [3] states that if a brand/product is to be launched, social media is used to spread information which in nature makes a friend or follower curious. That way, the brand name will be jacked up and much sought after or awaited by people.

\section{Theoretical Framework}

Social media from the root of the word social first refers to the communication strategy or the way people interact. Then the media is a communication tool like television, newspaper or radio. So social media is communication in 2 (two) directions through text, photos, video and audio distributed through the internet [4]. Social Media is a group of internet-based applications which is built on the ideological and technological foundation of web 2.0, which allows the creation and exchange of content created by users [5]. Social media is a real form of new media-based advances in communication technology supported by information technology and communication (Information and Communication Technology). Social media is understood as a new form of communication on the internet that is supported by various applications software, which allows interaction between users. Media social has several advantages, especially in its ability in interactive two-way communication, and makes it easy for users to access various kinds of information. This condition will be very supportive interactive communication without obstacles and distance. Inside is very possible social interaction occurs both between individuals, individuals with groups, groups with groups, even individuals and groups with mass. Some sites Popular social media at the moment are Facebook, Twitter and YouTube. The three of them will still dominate the world of social media for the next two years (Marketing, edition 10 / XIII / Oct 2013). The presence of social media can eliminate space and time limits, which has been a barrier in interacting for those who are in a far apart place. Under these conditions present the term that is called as global vilage. The term global village is a condition analogize the world as a large village where distance is no longer again a problem in communication. It can be said that the world has not again round but flat, because it is assumed that all individuals can be at a time together to interact simultaneously [6]. For the development of communication, social media and even allows increased value (value) of the actors.

Digital Start-up. The majority of businesses that have arisen in the modern era tend to be exploited through online media which is now called e-commerce. Start-up, a word that is often used in the current digital era, Sheung [7], explains that Business startup methods are followed by technological trend innovations. Pateli and Giaglis [8] stated that the acceleration of the growth of Information and Communication Technolog (ICT) is able to increase trends that are changing traditional or business models encourage the establishment of new businesses 
(startups) that tend to take advantage of opportunities technology. Business startups are able to grow or create new opportunities for young people especially those who are willing to adapt and change traditional market models to virtual markets. Old business models that are starting to change to online business model (startup) where inventory is replaced by information and digital products replace physical goods.

Digital Start-up Strategy. As explained earlier, the start-up business is included challenging business models because information often moves very fast, and consumers have many ways to get goods and services with fast without physical money [9]. Therefore, a player in the Digital business has a lot to find out how to get profits derived from the movement of information about the trend of goods and services. Digital business development is almost the same as physical business in general, one way is marketing. Beier [10] states that the marketing process in the digital world too must be understood by the owner of digital start up, digital marketing in general can defined as the use of integrated digital technology. Another definition also explains the targeted and measurable communication intended for get and keep customers and at the same time building deeper relationships with them [11]. Online marketing today can be done with new technologies such as smartphone and supporting applications [12].

Business Model. Business models are tools that explain how an organization creates, provide, and capture an added value [13]. A startup needs tools this is to provide a comprehensive view of the business processes to be planned, or even describe an ongoing business. Many businesses are just beginning to experience many obstacles during operation. Business models can help analyze problems and looking for a solution. New startups can use business models to design shapes according to the startup conditions. The business model is a model that is explained about how a company moves in achieving profits. This model is likened to a vehicle built by the company in order to get them to the place purpose. A startup needs the right business model to increase competitiveness and reach its final destination [14]. The supporting factor for a successful startup is the model good business, three advantages of having a good business model, which is being able to provide a view of the company about how the market responds to the products it has weaken the competitiveness of competing companies, and encourage partnership with companies competitors (mutualism) in creating products that are able to answer market needs. These benefits can be a key for the company to win competition in the market

Values in Social Media Integration. For the development of communication, social media allows improvement value (value) of the perpetrators, using the principle of building relationships between companies and followers or fans. The intended value here is how after the relationship between the two parties of social media is realized, there are positive impacts that not only affect one party, however also penetrated to a wider scope. The power of social media to aim at company and brand imaging, even able to reduce campaign costs which usually must be done conventionally by the company. Social media will form promising communication patterns more intensive interaction. In social media, public followers or fans are free express whatever you want to express. Full social media space can be controlled by followers or fans, that's why closeness (engagement) can be realized, because closeness is no longer distant with mutual interaction to meet the needs of followers. It can be said that there is a process of seeding (sowing) so that the message embryo from what the company has disseminated in social media, so that it is on can finally grow and develop. At the next level, it will be felt domino effect by all social media users. Communication patterns on the media This social is actually a process of transfer from the pattern of development groups, communities or crowds that exist in the real world transferred to cyberspace. The way that is 
adopted by social media, even can touch various lines of society who act as followers. So, in this context, the spirit raised is formation collaboration of social media users. In a journal belonging to Kim [15], the role of the media is explained social towards the company Start up, marketing through social media can help startup companies by: 1 . Increase in site visitors, by including links that point to your website on every post, your social media account followers will easier to visit your site. Social media is only as media A brief ad, in full, can be seen on your site. 2. Word of mouth promotion, social media allows everyone to connected to each other without knowing. You might not know A, but maybe B has shared or retweeted a post so A visited the account your social media. We recommend posting on social media made interesting maybe to generate viral value from social media. 3. Brand awareness, create a social media account that matches the site name this will make your "brand" or your site's name more affordable and easier to remember, more than that post on social media with the right frequency makes your site appear active 4 . Form a brand identity and positive brand association. Your site is what is posts, therefore posts on social media must be relevant with your site, according to the vision of your company. 5. Media communication and interaction with the target audience. Social media does not like traditional media, social media allows two communication direction, where responses from each post can be directly obtained. Media social can also be used to obtain public opinion.

\section{Research Methods}

The methodology in this research is the case study method. According to Kriyantono [16], the case study method is a research method that uses various data sources that can be used to research, describe and explain comprehensively various aspects of individuals, groups, a program, organization or event systematically. Case studies are research methods that use various data sources (as much data as possible) that can be used to research, decipher, and explain comprehensively various aspects of individuals, groups, a program, organization or event systematically. Study of various sources This data requires a variety of data collection instruments. The use of the case study method in the discussion of this journal is study a case with a focus on social media in the Infokost.id Startup business. Data obtained will be analyzed qualitatively ie the analysis carried out with understand and compile data that has been collected and arranged in a manner systematic, then draw conclusions. Pawito [17] argues that in qualitative research, the conclusions produced are generally not intended as generalization, but as an interpretive picture of reality or its phenomena researched holistically in certain settings Here, the findings are meaningful whatever is produced is basically limited to the case observed. Therefore, the principle of inductive thinking is more prominent in withdrawal conclusions in qualitative communication research.

\section{Results and Discussion}

\subsection{Social Media Infokost.id}

Infokost.id currently uses three Social Media in delivering messages to the public. Each social media that infocost uses has different forms of messages and advantages. The following are the social media used by Infokost.id: 
a) Facebook, with 11,648 likes. With Facebook Infokost.id provides information in the form of videos and images, the reason Infokost uses Facebook social media is because of the large number of users and the many features provided by Facebook so that integration is easy in conveying messages with Facebook social media.

b) Instagram, with 8,943 followers who are the number an active follower and actually not a fictitious follower. Reason Infokost uses Instagram, the first is because of the large number of users, the two messages that are given are photos and videos that are suitable as media that can be used to provide information in the form of images and videos that infocost has to offer.

c) Twitter with 6.634 followers. Currently infocost still using Twitter social media with many reasons Twitter social media users in Indonesia and are now starting to crowd again who are using this social media.
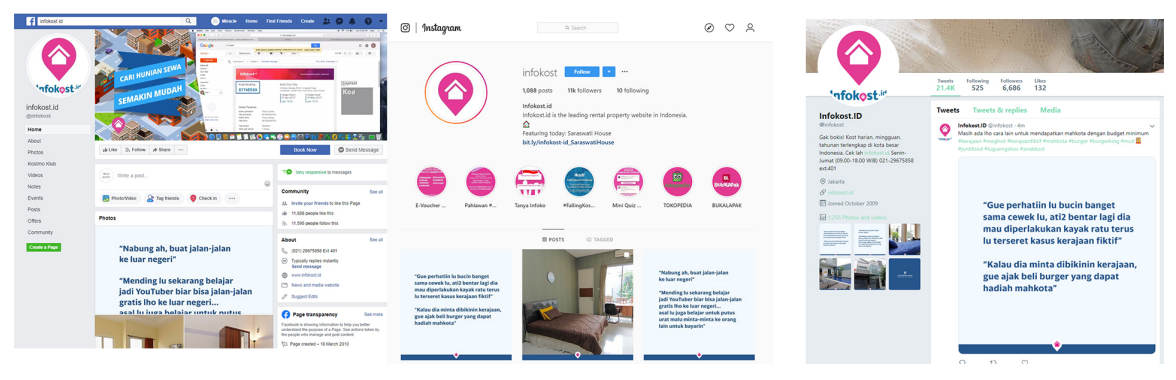

Fig. 1. Social media infokost.id

\subsection{Discussion}

Number of startup companies that utilize social media for activities show a phosphitive trend. This is supported by the increasing consumer response through social media to interact with companies. Media development social only reflects the shift of consumer confidence from producers to other consumers. The internet especially has become a very effective climate medium, and allows all types of business activities throughout the world to carry out effective and inexpensive communication anywhere in the world. For the long term with the increasingly intensive use of social media and 'feedback' make it easier to conduct surveys compared to the media conventional and the results are more real time, spontaneous and more objective. Caleb T. Carr and Rebecca A Hayes [18] social media is media Internet-based that allows users the opportunity to interact and present themselves, both instantaneously or delayed, to the public broad or not that drives the value of user-generated content and perception interaction with other people. Startup companies like the Infokost using a website as a business platform needs to always improve traffic to keep going and growing. Website traffic can be on define as the number of people visiting a website, which pages they see, and the length of time visitors see or read the page. Infokost.id's startup in creating content depends on its objective generally in addition to the information traffic that is delivered can be clearly on understand by the audience the need for a strategy in creating messages with integration social media. According to Daryanto (2010) bringing together to achieve communication to be effective, a minimum of two strategies is needed, the first is running aspects of communication, including the existence of clarity, accuracy, context, a systematic flow and pay attention to local culture applicable. Secondly build effective strategies, covering 
who becomes talk partners, what is the company's purpose for communication, pay attention culture, understanding linguistic style, understanding context, and using media and the right means. In delivering a message startup Infokost uses the media social as a medium to gain brand awareness by managing content activation on social media as an Infokost content marketing activity. So that can get optimal results there are several things that are important to be on pay attention, such as setting goals, setting target audiences, planning content, choose the right channel. In an effort to build brand awareness, Infokost.id and take advantage social media as a marketing tool. Strauss and Forst [19] mention social media is a term used online. social media itself has become a phenomenon for the people of the world to get information, even this is not spared from the eyes of business people to take advantage the ease of social media as a promotional media. According to Maharani [20] media social is the cheapest promotional tool and has a significant impact on it business because it has many users and does not require a fee to create a social networking account. Social media is a more intimate and accessible promotional media communicating interactively involving tourists and products and by itself can increase awareness. promotion message to the media social tailored to the needs of Infokost such as providing information about a boarding house with information as complete as you want known boarding house residents. Infokost researchers found that this startup using the Bulls Eye Technique, which is a technique that can be used for determine which social media is most appropriate to use in a Startup. The social media currently used by Infokost startups, namely: Facebook, Instagram and Twitter. The reason why Infokost chose to use media social is because the media users are many users and appropriate segment of the audience Infokost itself. In making cellphone Infokost content start with brainstorming every week the goal is to analyzing what social media I have appropriate content that will be created and post ideas that can be applied on social media Infokost. Infokost content is made interesting by following trends and not merely about Infokost information in making Infokost content also insert Tang content is a trend to make the audience not easily bored. Marketing by using social media this makes it easy in the startup business to study consumers. Consumer experience data obtained through social media can be used as a basis for future making a better content message going forward.

\section{Conclusion}

The determinants of business success for start-up-business on Infokost startups are good HR/Team, proper Timing, and also sufficient Idea and Funding. This shows that the good quality of human resources and the right timing really influence the success of the business which is still in the start-up stage. Therefore, startup companies must be able to see opportunities and the right time to make a product. Idea and Funding become a supporting factor for startup success. While the business model is not really needed in the initial phase of startup formation.

\subsection{Suggestion}

This research is a qualitative study in which the results of the study cannot be generalized to other companies outside the object of research. Therefore, researchers suggest that further research can conduct quantitative research to confirm the determinants of business success. 


\section{References}

[1] Y. Keat and S. Ahmad, "A study among university students in business start-ups in Malaysia: Motivations and obstacles to become entrepreneurs," Int. J. Bus. Soc. Sci., vol. 3, no. 19, 2012.

[2] P. Druker, "Innovation and entrepreneurship: Practice and principles," NY Harper\& Row, 1985.

[3] T. Abdullah and F. Tantri, "Manajemen pemasaran," Depok PT Raja Graf. Persada, 2012.

[4] M. Riese, L. Pennisi, and A. Major, "Using Social Media To Market Y Sheung, Chia Thian. 2014. E-Business; The New Strategies Ande-Business Ethics, that Leads Organizations to Success," Glob. J. Manag. Bus. Res., vol. XIV, no. VIII, 2010.

[5] A. M. Kaplan and M. Haenlein, "Users of the world, unite! The challenges and opportunities of Social Media," Bus. Horiz., vol. 53, no. 1, pp. 59-68, 2010.

[6] H. Hendroyono, "Brand Gardener," Jakarta Lit., 2012.

[7] C. T. Sheung, "E-Business; The New Strategies Ande-Business Ethics, that Leads Organizations to Success," Glob. J. Manag. Bus. Res., 2014.

[8] A. G. Pateli and G. M. Giaglis, "Technology innovation-induced business model change: a contingency approach," J. Organ. Chang. Manag., 2005.

[9] D. J. Teece, "Business models, business strategy and innovation," Long Range Plann., vol. 43, no. 2-3, pp. 172-194, 2010.

[10] M. Beier, 'Startups' Experimental Development of Digital Marketing Activities. A Case of Online-Videos," in A Case of Online-Videos (September 7, 2016). Paper has been presented at the 14th Interdisciplinary European Conference on Entrepreneurship Research (IECER), Chur, Switzerland, 2016.

[11] C. Wymbs, "Digital marketing: The time for a new 'academic major' has arrived," J. Mark. Educ., vol. 33, no. 1, pp. 93-106, 2011.

[12] M. T. P. M. B. Tiago and J. M. C. Veríssimo, "Digital marketing and social media: Why bother?," Bus. Horiz., vol. 57, no. 6, pp. 703-708, 2014.

[13] O. Alexander and P. Yves, "Business model generation," New Jersey, USA Willey, 2010.

[14] A. Uzzaman, StartupPedia. Bentang Pustaka, 2015.

[15] L. Kim, New Era of Business: Start-up and The Marketing. Boston: Word Stream Publisher, 2012.

[16] R. Kriyantono, S. Sos, and M. Si, Teknik praktis riset komunikasi. Prenada Media, 2014.

[17] Pawito, Penelitian Komunikasi Kualitatif. Yogyakarta: LKIS Pelangi Aksara, 2008.

[18] C. T. Carr and R. A. Hayes, "Social media: Defining, developing, and divining," Atl. J. Commun., vol. 23, no. 1, pp. 46-65, 2015.

[19] Strauss, Judy, and Frost, E-Marketing edisi internasional ke 6. London: Pearson, 2012.

[20] M. Maharani, A. H. N. Ali, and H. M. Astuti, "Faktor-Faktor PengaruhMedia Sosial Terhadap Keunggulan Bersaing: Studi Kasus Coffee Toffee Indonesia," J. Tek. ITS, vol. 1, no. 1, pp. A567-A572, 2012. 